Part of Journal of Research of the National Bureau of Standards, Volume 14, April 1935

\title{
RELATION OF INK TO THE PRESERVATION OF WRITTEN RECORDS
}

\author{
By Elmer W. Zimmerman, Charles G. Weber, and Arthur E. Kimberly ${ }^{1}$
}

\section{ABSTRACT}

The life of written records depends on the stability of both the paper and the ink. Investigation of the comparative resistance of inked and uninked specimens to the effects of an accelerated-aging test, consisting in heating the samples 72 hours at $100^{\circ} \mathrm{C}$, revealed that the rate of deterioration of writing papers was increased by the common type of writing inks. The effect on papers suitable for permanent records, which deteriorated very little when uninked, was more apparent than on papers of lower grade. An ink made with ammonium ammoniumoxyferrigallate was found to have a minimum of deleterious effect.

\section{CONTENTS}

Page

I. Introduction _...

II. Inks and papers studied

III. Procedure

IV. Results of tests

1. Comparative qualities of the inks tested............ 465

2. Relative effects of inks on different papers

3. Influence of ink on acidity of paper $\ldots \ldots \ldots 7$

4. Reproducibility of results

V. Summary and conclusions

\section{INTRODUCTION}

Many records are still preserved in manuscript form, the permanence of which depends upon the type of paper and ink used. A study of writing papecs at the National Bureau of Standards has revealed much information relative to the influence of the properties of paper and the conditions of storage on the lasting quality of record papers. ${ }^{2}$ The work of previous investigators ${ }^{3}$ shows that some inks have a deteriorative effect on paper. The published results are contradictory with respect to the effects of the separate components of ink on paper, and modern types of domestic record papers were not included in the experiments. The work here described was undertaken to obtain information regarding the effect of writing inks and their components on domestic papers.

\footnotetext{
${ }^{1}$ Formerly Research Associate at the National Bureau of Standards for the National Research Council.

${ }^{2}$ A. E. Kimberly and B. W. Scribner, Misc.Pub. BS M144 (1934).

${ }_{3}$ C. Wurster, Ber. Deut. Chem. Ges. 10, 1794 (1877).

O. Schluttig, and G. S. Neumann, Die Eisengallustinten, V. Zahn und Jaensch (Dresden, 1890)

P. Ehrle, Zentr. Bibliothekwesen. 15, (1898)

Posse. A pollo Press (Dresden, 1899).

O. Winkler, Z.angew, Chem. 16, 27 (1903).

A. J. J. Vandervelde, Rev. Bibliothéques Arch. Belgique 4, 77 (1906).

W. Haerting, Kolloid-Z. 25, 74 (1919).

W. Herzberg, Papierprüfung, p. 67 (Berlin, 1866).

W. Herzberg, Mitt. Materialprüfungsamt, Berlin-Dahlem, 40, 90 (1922).

W. Herzberg, Paper Makers' Monthly J. 61, 236 (1923).

W. Herzberg, Wochbl. Papier-Fabr. 55, 335 (1924); Chem. Abst. 18, 1750 (1924).
} 


\section{INKS AND PAPERS STUDIED}

Three inks were first prepared in the laboratory, using the specification for government standard writing ink ${ }^{4}$ as a guide. The first was made according to the specification. The second was a duplicate of the first, except that a chemically equivalent amount of sulphuric acid was substituted for the hydrochloric acid, and the third was like the second with one percent of gum arabic added. These inks are numbered 1,2, and 3 respectively in table 1 . Seven solutions, listed in table 2, were also prepared, each of which contained a different component or a combination of components of the concentration used in ink number 1. With the information on the action of these inks and the solutions of their ingredients as a guide, nine additional writing inks (numbered 4 to 12 in table 1) were prepared for testing. Materials of the ordinary reagent quality were used for all of the ingredients except the ferrous sulphate, which was purified by precipitation with alcohol. ${ }^{5}$

TABLE 1.-Test data on writing inks

Paper no. 7

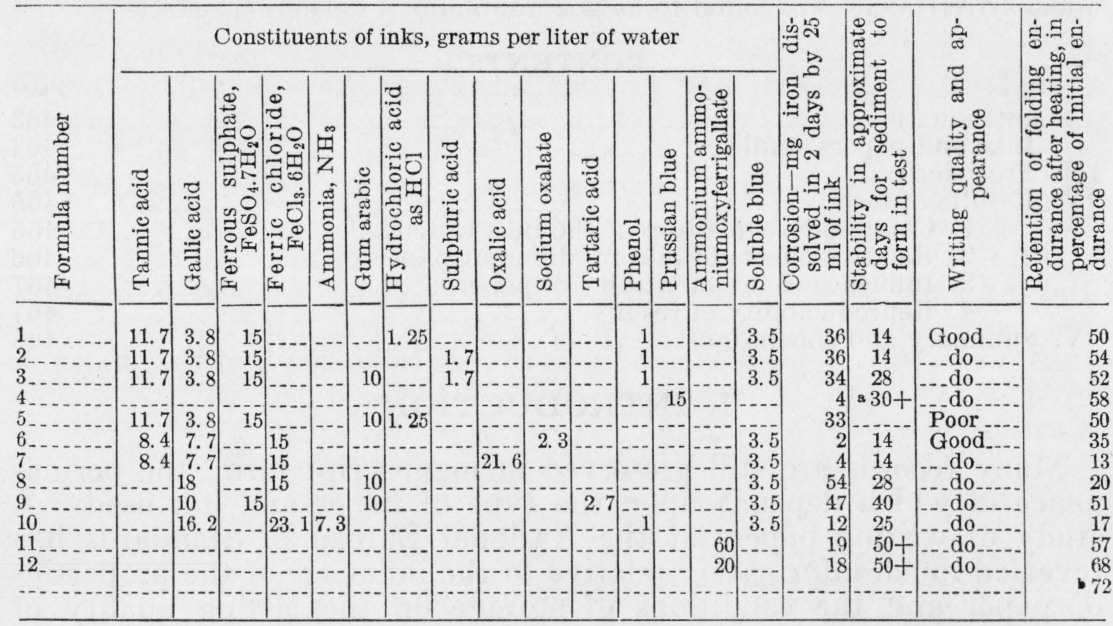

a + indicates test was stopped before a sediment appeared.

- Uninked paper.

TABLE 2.-The influence of ink constituents on the deterioration of paper no. 7 and on the corrosion of steel pens

\begin{tabular}{|c|c|c|c|}
\hline Solution & Ink constituents in solution & $\begin{array}{l}\text { Corrosion } \\
\text { of steel, } g \\
\text { of iron dis- } \\
\text { solved by } \\
25 \mathrm{ml} \text { of ink }\end{array}$ & $\begin{array}{l}\text { Retention of } \\
\text { folding endur- } \\
\text { ance after } \\
\text { heating, in } \\
\text { percentage of } \\
\text { initial endur- } \\
\text { ance }\end{array}$ \\
\hline D $\mathrm{D}$ & $\begin{array}{l}\text { Tannic acid, gallic acid, } \mathrm{FeSO}_{4} \\
\text { Tannic acid, gallic acid, } \\
\text { Tannic acid, gallie acid, } \mathrm{HCl} \\
\mathrm{HCl} \\
\mathrm{HCl}, \mathrm{FeSO}_{4} \\
\mathrm{HCl}_{4} \mathrm{FeSO}_{4} \text {, tannic acid, gallic acid } \\
\text { FeSO }_{4}\end{array}$ & $\begin{array}{l}.008 \\
.008 \\
.034 \\
.029 \\
.028 \\
.035 \\
.004\end{array}$ & $\begin{array}{r}57 \\
72 \\
70 \\
60 \\
59 \\
54 \\
60 \\
\times 72\end{array}$ \\
\hline
\end{tabular}

s Untreated paper.

- Federal Specification T T-I-563, Ink; Writing

s. Thorpe, Dictionary of Applied Chemistry, III, 861 (Longmans, Green, and Co., London, 1922). 
Seven writing papers, varying as to fiber composition and sizing materials, were selected for use in the tests. These papers are described in table 3 .

\section{PROCEDURE}

In order to determine the effect of the writing inks on the deterioration of paper, inked and uninked specimens of the papers were subjected to an accelerated-aging test ${ }^{6,7}$ that has been employed by this Bureau for estimating the relative permanence of papers. ${ }^{8}$

The inked specimens were prepared by drawing parallel lines approximately 0.02 inch wide, spaced 0.036 inch apart, across onehalf of each sheet of paper. The lines on half of the sheets were parallel to the machine direction of the paper, and on the others were at right angles to the machine direction. The sheets were conditioned two weeks in an atmosphere of 65 percent relative humidity at $70^{\circ} \mathrm{F}$ and then aged at $100^{\circ} \mathrm{C}$ for 72 hours. The folding endurance of the samples was determined on an MIT folding-endurance tester. ${ }^{9}$ The results of 20 tests, 10 made parallel to the machine direction and 10 made at right angles to the machine direction of the paper, were averaged to give each of the figures reported in the tables. In each case the folds were made at right angles to the ink lines. The relative stability of the inked and uninked specimens, as shown by the decrease in the retention of folding endurance after the acceleratedaging test, was considered indicative of the deteriorative effect of the ink on the paper. Inked and uninked specimens were conditioned and tested simultaneously.

All of the papers were tested with inks 1,2, and 3 in order to find the influence of the paper on the ink, and all the inks were tested on one paper to compare the relative effect of the different inks. The inks were also tested for sediment and corrosion by the methods given in the specification for writing ink ${ }^{10}$, and the writing quality was observed.

\section{RESULTS OF TESTS}

\section{COMPARATIVE QUALITIES OF THE INKS TESTED}

The standard writing inks were all found to be very harmful to the paper. The effects were so serious that further investigation was confined to different types of inks in an effort to find one less harmful to paper. Twelve inks were tested. The results of the tests are given in table 1. The inks containing ammonium ammoniumoxyferrigallate prepared according to the method of Silbermann and Ozorovitz ${ }^{11}$ gave promising results. These inks are identified in table 1 as nos. 11 and 12 , and the formulas are identical except that ink 12 is a weaker solution.

Tests of ink 12, made in duplicate, showed no significant harmful effect on paper. In addition to being the best ink tested as regards harmful effects on paper, this ink flowed well from a pen, did not form a sediment when exposed to the air for a month, and was only mildly corrosive to steel pens.

\footnotetext{
6 R. H. Rasch, BS J.Research 3, 476 (1929) RP107.

7 R. H. Rasch, and G. O. Stone, Paper Trade J. 95, T540 (July 1932).

8 R. H. Rasch, and B. W. Scribner, BS J.Research 11, 727 (1933) RP620.

Tech. Assn. Pulp \& Paper Ind., Paper Testing Methods, p. 62 (1929 ed.)

10 Federal Specification TT-I-563; Ink, Writing.

11 Bul. Soc. Stiinte 17, 43-57 (1908); Chem. Zentrbl. 1908, II, 1024.
} 
The only other ink tested that was less harmful to paper than the standard ink was made with a sample of soluble prussian blue purified by dialysis. The dried material dispersed very readily in water and did not precipitate on standing for months. When this ink came in contact with iron, the prussian blue precipitated on the metal in large flocks, which makes the ink unfit for use with steel pens.

The data in table 2 show that the deleterious effects of ink on paper can be attributed to the iron salt and the mineral acid. There was no apparent correlation between the corrosion of steel and the effects on paper. It is also shown that the total corrosion of steel caused by an ink is not dependent exclusively on the amount of mineral acid in it, because the effect of gallic and tannic acids is too large to neglect. This observation agrees with F. F. Rupert's ${ }^{12}$ findings. Data in table 1 indicate that inks made with hydrochloric acid are no more corrosive to steel than inks made with sulphuric acid.

The testing of the inks for sediment formation showed that the addition of gum arabic to ink apparently postponed the formation of sediment. Ink 2 , containing no gum arabic, had after 2 weeks only a slight sediment, which increased slowly. On the other hand, ink 3, made according to the same formula except for the addition of 1 percent of gum arabic, showed no sediment until the end of the fourth week. However, after the sediment began to form, it accumulated very rapidly and formed a thick sludge.

The inks were tested for permanence on paper by exposing inked specimens to the carbon-arc light of a Fade-Ometer. All were found to be practically unimpaired as regards legibility during the life of the paper, which indicated good resistance to fading.

\section{RELATIVE EFFECTS OF INKS ON DIFFERENT PAPERS}

The deteriorative effects of inks 1,2 and 3 on all of the papers were determined to find the relation between the composition of the paper and its susceptibility to deterioration by the action of the inks. A comparison of the deteriorative effect of inks 1,2, and 3 on the seven different papers is shown in table 3.

TABLE 3.-The effect of inks on the various papers

\begin{tabular}{|c|c|c|c|c|c|c|c|c|c|}
\hline \multirow{3}{*}{ Paper number } & \multicolumn{4}{|c|}{ Fiber composition, percent } & \multirow{3}{*}{ Sizing materials } & \multicolumn{4}{|c|}{$\begin{array}{l}\text { Retention of folding en- } \\
\text { durance after heating, in } \\
\text { percentage of initial }\end{array}$} \\
\hline & \multirow[b]{2}{*}{ Rag } & \multicolumn{2}{|c|}{ Sulphite } & \multirow{2}{*}{$\begin{array}{l}\text { Highly } \\
\text { purified } \\
\text { wood } \\
\text { fibers }\end{array}$} & & \multirow{2}{*}{$\begin{array}{l}\text { Un- } \\
\text { inked }\end{array}$} & \multicolumn{3}{|c|}{ Inked } \\
\hline & & Bleached & $\begin{array}{c}\text { Un- } \\
\text { bleached }\end{array}$ & & & & $\begin{array}{l}\text { Ink } \\
\text { no. } 1\end{array}$ & $\begin{array}{l}\text { Ink } \\
\text { no. } 2\end{array}$ & $\begin{array}{l}\text { Ink } \\
\text { no. } 3\end{array}$ \\
\hline & \begin{tabular}{r}
60 \\
60 \\
\hdashline \\
\end{tabular} & $\begin{array}{r}40 \\
40 \\
100 \\
50\end{array}$ & 50 & 100 & $\begin{array}{l}\text { Rosin and glue... } \\
\text { Rosin } \\
\text { Rosin and glue. } \\
\text { Rosin }\end{array}$ & $\begin{array}{l}83 \\
63 \\
42 \\
42 \\
23\end{array}$ & $\begin{array}{r}51 \\
43 \\
24 \\
0 \\
8\end{array}$ & $\begin{array}{r}41 \\
45 \\
23 \\
16 \\
9\end{array}$ & $\begin{array}{r}62 \\
50 \\
27 \\
17 \\
8\end{array}$ \\
\hline & & & & 100 & Rosin and starch & 98 & 48 & 55 & 74 \\
\hline & 100 & & & & Rosin and glue... & & & & \\
\hline
\end{tabular}

The figures in the table do not show any consistent relationship between the quality of the papers and their resistance to the deteriorating action of ink. In general, the action of ink on the good record

12 Ind.Eng. Chem. 15, 489 (1923). 
papers, which, when uninked, were almost unaffected by the aging test, was much more serious than its action on a poor grade of paper, which deteriorated rapidly even when uninked. This tendency is shared with sulphur dioxide. ${ }^{13}$ The kind of sizing had no significant effect on the resistance of the papers to the harmful action of the inks.

\section{INFLUENCE OF INK ON ACIDITY OF PAPER}

Some information on the increase in the acidity of the paper was obtained by testing inked and uninked specimens of paper no. 1 , ruled with ink no. 1, before and after heating. The results of these tests are contained in table 4.

TABLE 4.-Influence of ink on acidity of paper

[Paper no. 1. Ink no. 1.]

\begin{tabular}{|c|c|c|c|c|}
\hline \multirow[b]{2}{*}{ Specimen } & \multicolumn{2}{|c|}{$\begin{array}{c}\text { Acidity in terms of } \\
\text { percent } \mathrm{SO}_{3}\end{array}$} & \multirow{2}{*}{$\begin{array}{l}\text { Increase } \\
\text { on heating }\end{array}$} & \multirow{2}{*}{$\begin{array}{c}\text { Total } \\
\text { increase } \\
\text { over } \\
\text { original } \\
\text { uninked } \\
\text { specimen }\end{array}$} \\
\hline & $\begin{array}{l}\text { Before } \\
\text { heating }\end{array}$ & $\begin{array}{c}\text { After } \\
\text { heating } 72 \\
\text { hours at } \\
100^{\circ} \mathrm{C} \text {. }\end{array}$ & & \\
\hline $\begin{array}{l}\text { Uninked } \\
\text { Inked }\end{array}$ & $\begin{array}{r}\text { Percent } \\
.114 \\
.169\end{array}$ & $\begin{array}{r}\text { Percent } \\
.123 \\
.220\end{array}$ & $\begin{array}{r}\text { Percent } \\
8 \\
36\end{array}$ & $\begin{array}{r}\text { Percent } \\
93\end{array}$ \\
\hline
\end{tabular}

While the data in table 4 were obtained on one paper and one ink only, they show that the total acidity of paper was increased by the use of a harmful ink; also, that the acidity of the inked paper increased much more rapidly under the accelerated-aging treatment than did that of the same paper uninked. High acidity accelerates the deterioration of paper fibers.

\section{REPRODUCIBILITY OF RESULTS}

Three different tests were made to determine the reproducibility of the results. These tests were made from 6 months to a year apart by different operators using different preparations of the same inks. The results of these tests, listed in table 5, are within the limits of the maximum deviation obtained in testing the untreated paper.

TABLE 5.-Tests to show reproducibility of results

[Paper no. 7]

\begin{tabular}{|c|c|c|c|}
\hline \multirow{2}{*}{ Ink number } & \multirow{2}{*}{ Date of test } & \multicolumn{2}{|c|}{$\begin{array}{l}\text { Retention of fold- } \\
\text { ing e ndura n ce } \\
\text { after heating } 72 \\
\text { hr at } 100^{\circ} \mathrm{C} \text {. }\end{array}$} \\
\hline & & $\begin{array}{c}\text { Uninked } \\
\text { paper }\end{array}$ & $\begin{array}{l}\text { Inked } \\
\text { paper }\end{array}$ \\
\hline $\begin{array}{l}44, \text { same lot } \\
44-\mathrm{B} \text {, } \\
44-\mathrm{B} \text {, different lot }\end{array}$ & $\begin{array}{lr}\text { Nov. } 7,1932 \\
\text { June } 8,1933 \\
\text { June } 1,1933 \\
\text { May 21, } 1934 \\
\text { Aug. 25, } 1933 \\
\text { May 21, } 1934\end{array}$ & $\begin{array}{r}\text { Percent } \\
74 \\
71 \\
73 \\
77 \\
61 \\
74\end{array}$ & $\begin{array}{r}\text { Percent } \\
55 \\
51 \\
58 \\
67 \\
61 \\
66\end{array}$ \\
\hline
\end{tabular}

${ }^{13}$ A. E. Kimberly, BS J.Research 8, 159 (1932) RP407. 


\section{SUMMARY AND CONCLUSIONS}

Iron-gallotannate ink, prepared according to the government formula for standard writing ink, was found to greatly accelerate the deterioration of the papers in the heat test. The effect on papers suitable for permanent records, which deteriorated very little when uninked, was more apparent than on the papers of lower grade.

Of those inks tested, a type of ink containing ammonium ammoniumoxyferrigallate, prepared according to the method of Silbermann and Ozorovitz, had the least harmful effect on paper. This ink had good writing quality, was stable and only mildly corrosive to pens, and the deleterious effects on the paper were negligible. It appears to be a satisfactory record ink.

Washington, February 5, 1935 